\title{
Phylogenetic Patterns of Genus Megophrys (Anura: Megophryidae) from Java and Sumatra
}

\author{
Nia Kurniawan ${ }^{1 *}$, Aminuddin Affandi ${ }^{2,4}$, Erintha E. Wardani ${ }^{1}$, Indah N. Chomsy ${ }^{1}$, \\ Anggun S. Firdaus ${ }^{3}$, Agung S. Kurnianto ${ }^{4}$ \\ ${ }^{1}$ Department of Biology, Faculty of Mathematics and Natural Sciences, University of Brawijaya, Malang, Indonesia \\ ${ }^{2}$ Faculty of Agriculture, University of Brawijaya, Malang, Indonesia \\ ${ }^{3}$ Departement of Life Science, National Central University, Taiwan \\ ${ }^{4}$ Graduate School, University of Brawijaya, Malang, Indonesia
}

\begin{abstract}
The emergence of Java and Sumatra islands at the end of Miocene, has impact to the diversity of fauna that living in the islands. Amphibia, as one of a genetic information series, can be used as a good phylogenetic comparison. Genus Megophrys (Anura: Megophryidae), is a member of amphibians that live isolated at an altitude of 1000 ASL (Above Sea Level) or more. The purpose of this research is to analyze the phylogenetic patterns of genus Megophrys in Java and Sumatra based on the analysis of 16s rRNA gene. We also analyzed the zoogeography to understand the history of relationship and the establishment of these islands. We took samples on 12 localities: 10 areas of Sumatra and 2 areas of Java. We used Qiamp Blood and Tissue Kit to extract the DNA from tissues. Qualitative analysis of DNA was done by running electrophoresis on $1 \%$ agarose gel. Qualitative analysis of DNA was done by running electrophoresis on $1 \%$ agarose gel. Results show that Clade A has 2 subclasses: I and II. Subclade I consists of Sumatran specimens, whereas subclade II consists of Javanese specimens. Subclaude I and II have paraphyletic connections. Clade B classified as politomy clade consists of Megophrys sp. from West Pasaman, Megophrys sp. from West Sumatra and Megophrys sp. from Pasawaran, Lampung. The result shows that Megophrys sp. of subclade I (clade A) and clade B, belongs to the same group, both of them were originated from Sumatra. Megophrys sp. subclade I (clade A) originated from Tanggamus (Lampung) and West Lampung (Lampung) separated with 2 species of Megophrys sp. of clade B originated from Pasawaran (Lampung).
\end{abstract}

Keywords: 16s rRNA, Java, Megohprys, Sumatra, zoogeography

\section{INTRODUCTION}

Java and Sumatra islands emerged at the end of Miocene era. It has impact to the diversity of fauna living there [1]. Genetic factor contributes greatly on determining the relationships among fauna, as well as being the key for studying it's distribution time [2]. Amphibia is one of a genetic information series that can be used as good relationship comparison. Due to its small roaming, high dependence on microhabitat, and population limitations, it makes amphibia an attractive option on understanding a historical biogeography $[2,3,4]$.

Genus Megophrys (Anura: Megophryidae) is a member of amphibians that live isolated at an altitude of 1000 ASL (Above Sea Level) or more [5]. This frog is easily recognized by the 'hornlike' eyelids [6]. Javan horned frog, Megophrys montana, is an endemic species from Java [5].

\footnotetext{
* Correspondence address:

Nia Kurnaiawan

Email : wawan@ub.ac.id

Address : Dept. Biology, Faculty of Mathematics and Natural Sciences, University of Brawijaya, Veteran Malang, Malang 65145.
}

Other species were dispersed in Sumatra, Malayan horned frog M. nasuta, was also found spread from Yala, Thailand, Malay Peninsular, Sumatra, Kalimantan, to the Natuna Islands [7]. Megophrys were not an endangered genus in the world, but their presence are limited to certain of localities [8]. The purpose of this research is to analyze the phylogenetic patterns of genus Megophrys in Java and Sumatra based on the analysis of 16s rRNA gene. We also analyzed the zoogeography to understand the history of relationship and the establishment of these islands.

\section{MATERIALS AND METHODS \\ Data Collection}

We took samples on 12 localities: 10 areas of Sumatra and 2 areas of Java. Sampling was done by catching directly method on hills and mountains above $1000 \mathrm{mdpl}$ (Table 1). Samples preserved by injection of $70 \%$ alcohol in the heart of the animals. DNA obtained from animals by dissecting abdomen right to the chest, to get DNA sample of liver or tissue on the femur. We added SDS and EDTA to the tissues then inserted into the sample tube. The animal samples were 
injected with formaldehyde solution thoroughly then soaked in alcohol (wet preserved).

\section{DNA Extraction, Isolation, and Amplification}

We used Qiamp Blood and Tissue Kit to extract the DNA from tissues. Procedure was done by took $25 \mu \mathrm{L}$ of the tissue, added by $180 \mu \mathrm{L}$ ATL buffer. The solution homogenized by vortex. Homogenate added with $20 \mu \mathrm{L}$ of proteinase $\mathrm{K}$, then homogenized using vortex. Homogenate solution incubated in waterbath at $56^{\circ} \mathrm{C}$ to complete a lysis solution.

The solution homogenized for 15 seconds, added by $200 \mu \mathrm{L}$ of AL buffer, homogenized, then added by $200 \mu \mathrm{L}$ of absolute ethanol (96-100\%), re homogenized. Homogenate solution took using micropipette into $2 \mathrm{~mL}$ collection tube (equipped with Qiamp mini spin column). Solution centrifuged at $6000 \times \mathrm{g}(8000 \mathrm{rpm})$ for 10 minutes. Qiamp Mini spin column was placed on new $2 \mathrm{~mL}$ collection tube, added with $500 \mu \mathrm{L}$ of the AW1 buffer, centrifuged at $6000 \times \mathrm{g}$ for 1 minute. Qiamp Mini spin columns were placed into $1.5 \mathrm{~mL}$ microtube, added $200 \mu \mathrm{L}$ of $\mathrm{AE}$ buffer, then incubated for 1 minute at room temperature. After that, the solution was centrifuged at $6000 \times \mathrm{g}$ for 3 minutes.

Qualitative analysis of DNA were done by running electrophoresis on $1 \%$ agarose gel. Electrophoresis started by a gel-making process. Mixture consist of 0.2 grams of agarose powder,
$20 \mathrm{~mL}$ TBE buffer, and $1 \mu \mathrm{L} \mathrm{EtBr}$ solution. Agarose powder poured into a beaker glass, added $20 \mathrm{~mL}$ TBE solution, then boiled. Boiled gel cooled down for a while then added by $1 \mu \mathrm{L}$ EtBr. The gel poured into the a gel tray with the well comb in place. Agarose gel were loaded into gel electrophoresis box and added $1 \mu \mathrm{L}$ Loading dye and $1 \mu \mathrm{l}$ extract DNA on each gel's lane. Marker (100bp Benstop) put at the first lane of the gel. Negative control made by put $1 \mu \mathrm{L}$ loading dye into the gel's lane. Filled gel's run at $90 \mathrm{~V}$ for \pm 45 minutes. Electrophoresis results were documented using Gel Doc- UV Transiluminator.

PCR mix solution's composition in each PCR tube are $3.6 \mu \mathrm{L}$ ddH20, $5 \mu \mathrm{L}$ PCR mix (Go Taq Green), $0.2 \mu \mathrm{L}$ primer of 16 SBR (forward) (5'-CCG GTC TGA AC TCA GAT CAC GT-3 '); $0.2 \mu \mathrm{L}$ primer of 16 SAR (reverse) (5'-CGC CTG TTT ATC AAA AAC AT-3 '); $0.5 \mu \mathrm{L}$ extract of DNA. Forward and reverse primer stocks were eluted by mixed $1 \mu \mathrm{L}$ primer with $9 \mu \mathrm{L}$ Free Nuclease Water or TE buffer (Tris - EDTA). PCR's cycle repeated for 34 times by predenaturation at $95^{\circ} \mathrm{C}$ for 3 minutes, denaturation at $95^{\circ} \mathrm{C}$ for 30 seconds, annealing at $52^{\circ} \mathrm{C}$ for 60 seconds, extension at $72^{\circ} \mathrm{C}$ for 60 seconds, and post-extension at $72^{\circ} \mathrm{C}$ for 7 minutes for each cycle. The PCR product was purified with PCR sequence added by PCR kit. The amplified gene was examined on $2 \%$ agarose gel to perform electrophoresis.

Table 1. Megophrys sp. samples used on this research

\begin{tabular}{|c|c|c|c|c|}
\hline Sample's Code & Species & Locality & Island & Accession Number \\
\hline Megophrys sp_10 & Megophrys sp. & Pasawaran District, Lampung & Sumatra & MG012872 \\
\hline Megophrys sp_11 & Megophrys sp. & Pasawaran District, Lampung & Sumatra & MG012881 \\
\hline Megophrys sp_7 & Megophrys sp. & West Lampung, Lampung & Sumatra & MG012873 \\
\hline Megophrys sp_5 & Megophrys sp. & Ogan Komering Ulu District, South Sumatra & Sumatra & MG012874 \\
\hline Megophrys sp_6 & Megophrys sp. & Tanggamus District, Lampung & Sumatra & MG012875 \\
\hline Megophrys sp_9 & Megophrys sp. & West of Pasaman District, West Sumatra & Sumatra & MG012876 \\
\hline Megophrys sp_1 & Megophrys sp. & Toba Samosir, North Sumatra & Sumatra & MG012882 \\
\hline Megophrys sp_2 & Megophrys sp. & Humbang Hasundutan, North Sumatra & Sumatra & MG012879 \\
\hline Megophrys sp_3 & Megophrys sp. & Karo, North Sumatra & Sumatra & MG012883 \\
\hline Megophrys sp_4 & Megophrys sp. & Mandailing Natal, North Sumatra & Sumatra & MG012880 \\
\hline
\end{tabular}

\section{Data Analysis}

The isolated DNA that has been amplified were sequenced at Uniseck Laboratory GATC, Germany. The quality of sequences were checked and combined for forward and reverse sequences using $A B$ Sequence Scanner. The results confirmed using BLAST to confirm the species. Sequence data has been submitted to GenBank (https://www.ncbi.nlm.nih.gov) and can be accessed online after January 2017.
Sequences data from the genus Megophrys used to compare and outgroup species built by taken molecular data from GenBank (http://www.ncbi. nlm.nih.gov) (Table 2).

The sequence result aligned using MEGA 6.0. Reconstruction of phylogenetic trees was performed by using Maximum Parsimony (MP), Maximum Likelihood (ML), and Bayesian Inference (BI) the analyzed using PAUP * 4.0b10 [9]. General Time Reversible (GTR) of DNA 
evolution was analyzed using the gamma parameter [10]. The ML modeling on PAUP were analized using Jmodeltest program. BI and Bayesian Posterior Probabilities (BPP) were estimated using Mr.Bayes 30b4 [11]. Analysis of $\mathrm{BI}$ by using Monte Carlo Markov Chains (MCMC) for 6000000 generations and burn in $=3,000,000$. MP analyzed for non parametric bootstrapping for 1000 pseudoreplication on PAUP and 100 replications on ML analysis [12]. Genetic distance analyzed using MEGA 6.0.

Table 2. Sequences Data of the Genus Megophrys and Outgroup Species From GenBank

\begin{tabular}{lcl}
\multicolumn{1}{c}{ Species } & $\begin{array}{c}\text { Accesion } \\
\text { Number }\end{array}$ & \multicolumn{1}{c}{ Locality } \\
\hline M. acuta & KJ579124 & $\begin{array}{l}\text { Guangdong, } \\
\text { China }\end{array}$ \\
M. nankiangensis & AY526200 & $\begin{array}{l}\text { Sichuan, China } \\
\text { Guangdong, } \\
\text { M. obesa }\end{array}$ \\
KJ831312 & China \\
M. omeimontis & AY561307 & Sichuan,China \\
M. spinatus & AY526205 & Sichuan,China \\
Leptobrachium mangyanorum & GQ995556 & Philippines \\
L. tagbanorum & GQ995552 & Philippines \\
\hline
\end{tabular}

\section{RESULT AND DISCUSSION}

Phylogenetic Tree of Genus Megophrys

Clade A has 2 subclasses: I and II (Fig. 1). whereas subclade II consists of Javanese specimens. Subclaude I and II have paraphyletic connections. These results are supported by high MLBS values $(\mathrm{MPBS}=82 \% ; \mathrm{MLBS}=57 \% ; \mathrm{BPP}=$ $100 \%$ ) [13]. The laa and lab group have a monophyletic relationship, but the data is only supported by MPBS (MPBS = 97\%; MLBS = 65\%; $\mathrm{BPP}=71 \%)$. Boostrap values in phylogenetic tree branches were considered significant (70\%) [13]. The laa group consists of Megophrys sp. (1) originated from Toba, Megophrys sp. (2) from Humbang Hasundutan, Megophrys sp. (3) from Karo, and Megophrys sp. (4) from Mandailing Natal (North Sumatra).

Megophrys sp. originated from Toba Samosir and Mandailing Natal were closely related to $p$ distance $=0$ and supported with high bootstrap values (MPBS = 99\%; MLBS = 100\%; BPP = 100\%). Megophrys sp. originated from Humbang Hasundutan and Karo also shows a close relationship ( $p$-distance $=0$ ). Megophrys sp. of Toba Samosir and Karo are closely related and considered as the same species ( $p$-distance = 0.01). Megophrys sp. (4) from Mandailing Natal is the sister lineage of the three species with $p$ distance $=0.01$ which is still related in the same species (MPBS / MLBS / BPP = 100\%).

Subclade I consists of Sumatran specimens,

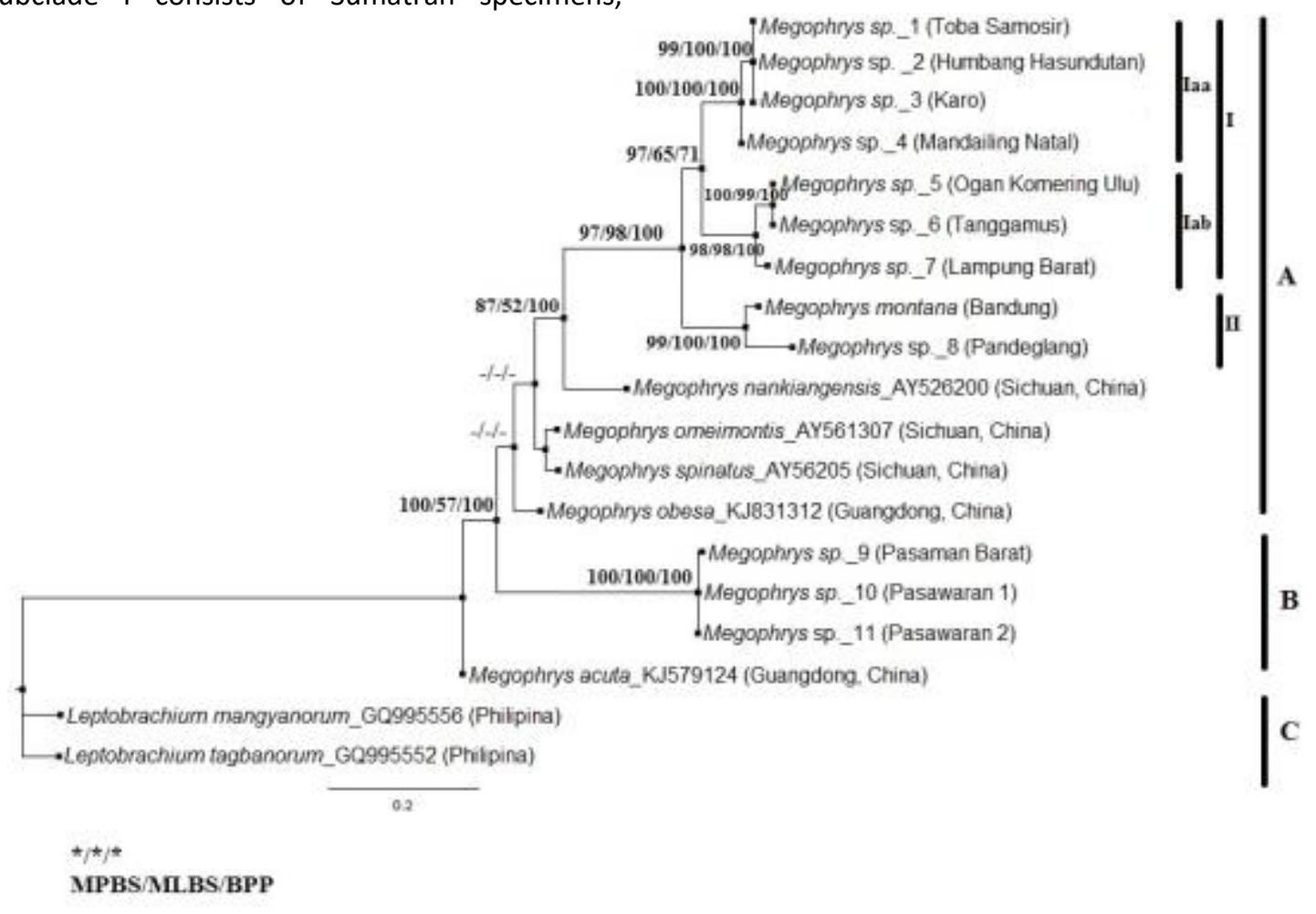

Figure 1. The Phylogenetic Tree of Genus Megophrys from Java and Sumatra based on 16S rRNA Analysis 
All species in the lab group were closely related and probably still in a species ( $p$-distance $<0.05)$. The lab group consists of Megophrys sp. (5) from Ogan Komering Ulu, Megophrys sp. (6) from Tanggamus, and Megophrys sp. (7) from West Lampung (Lampung). Based on p-distance analysis, Megophrys sp. from Ogan Komering Ulu and Tanggamus are in a close relationship ( $p$ distance $=0.00)(\mathrm{MPBS}=100 \%$; $\mathrm{MLBS}=99 \%$; BPP $=100 \%$ ). Megophrys sp. from West Lampung is the sister lineage of Megophrys sp. from Ogan Komering Ulu and Tanggamus (MPBS = 98\%; MLBS $=98 \% ;$ BPP $=100 \%)$. Megophrys sp. from Ogan Komering Ulu and West Lampung are still closely related in a species ( $p$-distance $=0.03$ ). Megophrys sp. from West Lampung and Tanggamus showed intraspecies relationship ( $p$ distance $=0.03$ ). Based on the $p$-distance value, the three species of Megophrys sp. of the lab group are still closely related in the same species.

Subclade II consists of $M$. montana species originated from Bandung, West Java and Megophrys sp. (8) from Pandeglang, Banten. Based on $\mathrm{p}$-distance analysis, $M$. montana from Bandung and Megophrys sp. from Pandeglang isnot included as the same species, shown by $p$ distance $=0.06$ (MPBS $=99 \%$; MLBS $=100 \%$; BPP $=100 \%)$. M. nankiangensis (Sichuan, China) is a sister lineage of the la and Ib groups, and was the only species supported by high bootstrap MPBS and $\mathrm{BPP}$ values (MPBS = 82\%; MLBS $=57 \%$; and BPP $=100 \%)$.

Clade B classified as politomy clade consist of Megophrys sp. (9) from West Pasaman, Megophrys sp. from West Sumatra (10) and Megophrys sp. (11) from Pasawaran, Lampung. The three species of Megophrys sp. closely related to on $\mathrm{p}<0.05$ (MPBS / MLBS / BPP = $100 \%)$ value. The three species of Megophrys sp. have $98 \%$ resemblance to $M$. nasuta. Uniquely, $M$. acuta (Guangdong, China) considered as the sister lineage of the three species of Megophrys sp. from Pasaman Barat, Pasawaran 1, and Pasawaran 2.

\section{Zoogeography}

The result shows that Megophrys sp. of subclade I (clade A) and clade $B$, belongs to the same group, both of them were originated from Sumatra. Megophrys sp. subclade I (clade A) originated from Tanggamus (Lampung) and West Lampung (Lampung) separated with 2 species of Megophrys sp. of clade B originated from Pasawaran (Lampung). Hypothetically, the location of the species is close to each other and should be able to construct the same clade. The p-distance values of these species indicate a considerable genetic distance to each other ( $p-$ distance> 0.020). The topography of the Bukit Barisan Mountains, most likely, affects this phenomenon. Other areas that have splited between subclade I (clade A) and clade B are Ogan Komering Ulu, Tanggamus, West Lampung, Pasaman and Pasawaran, surrounded by highlands, hills, up to mountains that its height more than 2,000 meters. Those barriers can be lead to the separation and genetic isolation process.

The construction of phylogenetic tree shows the relation of zoogeography, where the dispersal areas of Megophrys sp. took place on clade A (subclass I and subclass II) consists of northern, western, southern area of Sumatra, and Java (Fig. 2). Meanwhile, Megophrys sp. on clade B separated into subclass I which is also originated from Sumatra. Subclade II that was consist of $M$. montana from Bandung, West Java and Megophrys sp. from Pandeglang Banten have a proximity to subclass I originated from West Lampung, Ogan Komering Ulu, and Tanggamus. The dispersal of species Megophrys sp. from the northern part of Sumatra to the southern part of Sumatra was indicated by the species on subclade II and clade B. It can be explained by the geographic history of the Pleistocene epoch (1.8-0.01 MYA), when rivers from northern Sumatra and the western part of Malay Peninsula, formed a stream known as the Straits of Malacca nowadays. The ancient river system provided spreading pathways for amphibia [2].

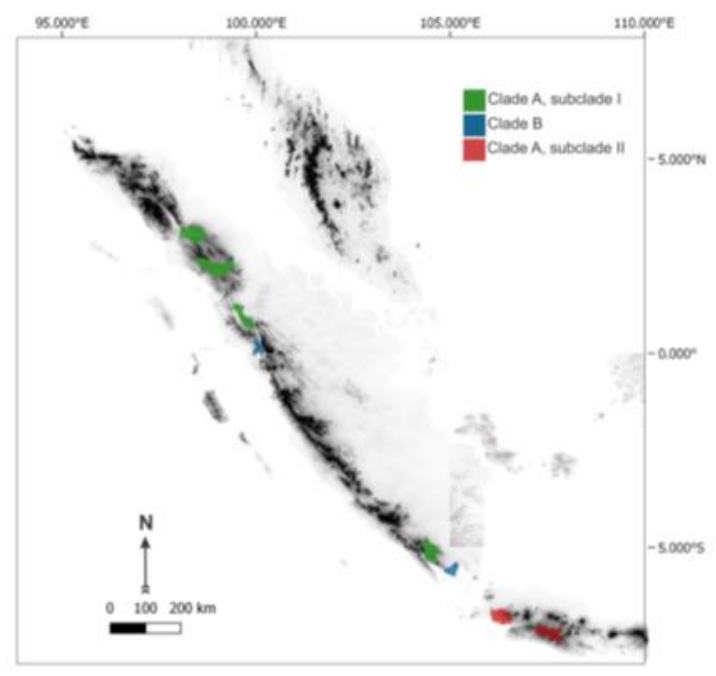

Figure 2. Distribution Map of Megophrys species from Java and Sumatra based on Phylogenetic Analysis 
Twenty five percents of species from Java Island come from Borneo and $43 \%$ of species may come from Sumatra. A total of 20 non-endemic species of Java are also known in Sumatra. These species was predicted that had reached Java in the last few millenium. Several species from Sumatra which commonly found in Java, can be found in lowland areas [5]. The exchange of fauna between Java and Sumatra is likely occured several times during the Pleistocene period due to the merge of the two islands and the loss of the Sunda strait [2].

Geologically, Sumatra has been much more stable than Kalimantan or the Malay Peninsula. During the epoch of Miocene, when most of Kalimantan and the Malay Peninsula areas might still be a mainland, the Sumatra's areas were mostly flooded and separated, then fragmented into a small volcanic island [14]. The exchange of amphibia may also occured in the epoch of Miocene (23.5-5 MYA) and Pliocene (5-1.8 MYA) affects to the spread of $M$. montana in Java [5].

The exchange of fauna occured after the formation of a broad topographic areas at the beginning of the epoch Pleistocene (Fig. 3). This exchange allowed fauna from the Malay Peninsula to have several similarity to Kalimantan and Sumatra fauna. However, it actually has greater similarity to Sumatra fauna. The regression of the sea level between Sumatra and the Malay Peninsula at that time, reached up to 30 meters, allowing a sub-aerial dispersal route between the Malay Peninsula and Sumatra.

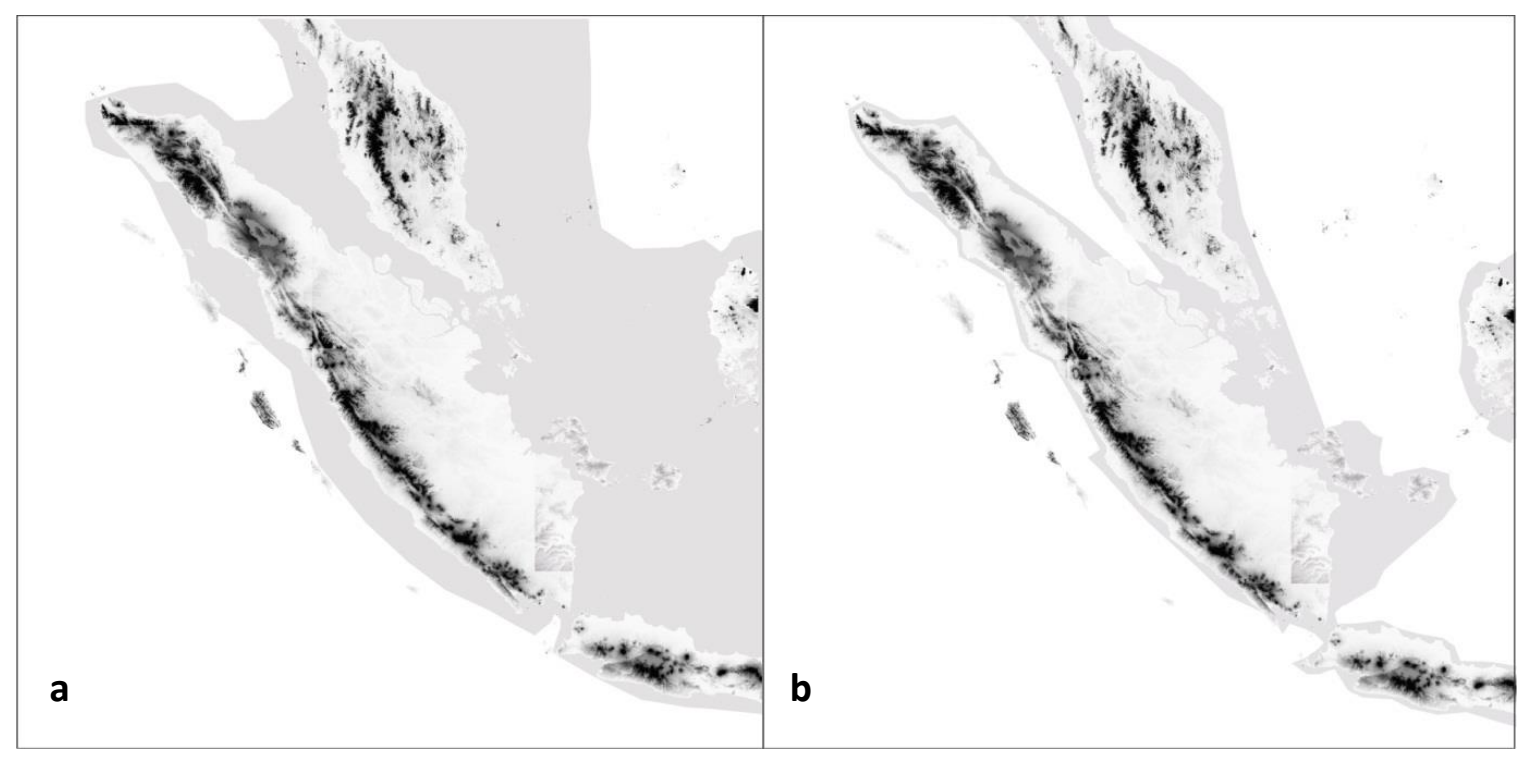

Figure 3. Siltation of the Sunda Strait which Resulted in the Merge of Java, Sumatra and the Malay Peninsula During the Pleistocene Epoch (redrawn from Inger and Voris [2])

Description: a) At the maximum lowering of sea level (120 meters from current surface-below present level); b) At 30 meters from the current surface

This spread of the species were carried out by the non-endemic fauna of Sumatra, the most diversity species originated from the Malay peninsula. Megophrys nasuta, as one of the nonendemic species, can breed in ancient rivers that was still connected the two lands. It is different with the exchange of the species on Malay peninsula and Sumatra, where between Sumatra and Kalimantan was more difficult to be carried out into, because of the connected periods for both islands are shorter. This phenomenon considered as the reason why the pattern among the fauna has a less similarity [2].

Species's distribution of the genus Megophrys, one them is $M$. nasuta, started from the Malay Peninsula and Sumatra. M. nasuta experienced a sympatric speciation in Kalimantan and a long period of isolation in the Tertiary era. $M$. nasuta probably reached its distribution areas as well on modern period when the Pleistocene epoch, when the seawater regression was maximized. The ability to reproduce and tolerance to dry climates indicate that these species are able to survive at the relatively dry Pleistocene epochs on Sundaland [2].

Sympatric speciation could be defined as the result of reproductive isolation without any geographical isolation [15]. Geographical isolation occurs when the distance between population exceeds the ability of individuals to 
spread or when the environment is not appropriate thus hindering the spread of population. Geographical barriers are an extrinsic factor of the environment which is affects all individual, independent and genotype.

Unclear and random situations could arise because of the extrinsic barrier of the environment that affects the biological nature of each individual. Sympatric speciation also defined between populations that initially used two different habitats but then experienced a free distribution [16]. Coyne and Orr [17] predicted that the species arised from sympatric speciation, by the most of them have overlapping geographic ranges. The spatial scale to determine the overlapping areas must be balanced with the organism's dispersal ability. In principle, species originated through sympatric speciation can be allopathric at over time [18].

Clade that predicted as a construction through sympatric speciation must be a sister species or monophyletic. All speciation processes occured in several geographical contexts and depend on the spatial distribution of biodiversity and considered as mechanisms of speciation. The geographical structure of habitats always plays a role on the process of sympatric, parapatric, and allopathic speciation, and also on the population divergence then lead to the change from allopathric to sympatric [19] or vice versa [18].

Allopatric speciation can occurs through the separation of one population into an ecologically divided area, but physically, it is not an appropriate habitat [20], or it may be said that the allopathic speciation is a divergence niche [21]. Population which comes from an allopathic speciation, experienced by individuals from different areas, impacts to the limits of species' range and its distribution [22]. Barrier supports a new population to find an appropriate and suitable habitat. The existing barrier types are influenced by the presence of substantial physographical transitions or other geological features, such as rivers and mountains as a range of inhibiting species's dispersal [23]. Thus, the effect of the barrier appears as an intrinsic response of species with wide environmental variations. Barrier types may vary geographically, so they may change over a short period of time [24].

Based on the nature of the cycle and the rate process of the ecological changes, this process then called as soft vicariance and become important in a speciation process [25]. In the case of physical inhibition, where the distribution was geographically limited, the effect of climate on a broad population distribution may has no effect. The isolation occured under these conditions is not due to the reduction of distribution capabilities, but rather to the intrinsic ecological conditions that have been applied as barriers [26]. These barrier's condition is depicted on the Sumatra Island. From the northeast to the southwest, the geology of the Sumatra Island is characterized by the sedimentary basins, and several of mountain ranges which has formed volcanic arc and fractals [27].

In addition, Sumatra Island, especially on the South area, has so many valleys. These valleys occured as the result of volcanic activity in the subduction zone. Sundaland or Sundanese plate, including Sumatra, since the early of Tertiary era, was generally experienced a slope towards the South [28]. Then, the subduction system in Sumatra as we can see on the west coast of Sumatra and southern Java has begun since the epoch of Oligocene. However, the formation of Barisan Mountains which arised from this subduction process, was began at the end of the Miocene epoch, around the epoch of PlioPleistocene (1.8-0.01 MYA) [29]. This volcanic activity then continually conceals some of the surface of the South Sumatra's basin [30], thus separates the species between subclade I (clade A) and clade B, even though it is located in an adjacent area.

\section{CONCLUSIONS}

The reconstruction of phylogenetic trees shows 3 main clades: clade A (parts of Sumatra, Java, and China/GenBank), clade B (Sumatra), and clade $C$ (outgroup). The dispersal of genus Megophrys in Sumatra is predicted through the ancient river flows from the Malay peninsula in the north to Sumatra and Java during the Pleistocene era. The species dispersals were likely possible because of the silting of the Sunda Strait. The Barisan Mountains, which ranges from north to south and also the basins and valleys became a greater barrier for subclass I (clade A) and clade B. Genus Megophrys were estimated to experience a sympatric speciation and distributed during the Pliocene era when the regression of sea water was maximized.

\section{ACKNOWLEDGEMENTS}

We are very grateful to NK research members, especially A.M. Kadafi, because of his hard work in the Java-Sumatra expedition (2016) to collect samples. We are also thankful to 
Mulyadiane for his help in making many corrections and improvements to the experimental procedure. We are also grateful for the revisions, suggestions and criticisms for Prof. Nashi Widodo for the preparation of the earliest manuscripts.

\section{REFERENCES}

[1] How, R.A., D.J. Kitchener. 1997. Biogeography of Indonesian snaker. J. Biogeogr. 24. 725-735.

[2] Inger, R.F., H.K. Voris. 2001. The biogeographical of the frogs and snakes of Sundaland. J. Biogeogr. 28. 863-891.

[3] Emerson, S.B., R.F. Inger, D. Iskandar. 2000. Molecular systematics and biogeography of the fanged frogs of Southeast Asia. Mol. Phylogenet. Evol. 16. 131-142.

[4] Matsui, M., A. Tominaga, W.Z. Liu, W. Khonsue, L.L. Grismer, A.C. Diesmos, I. Das, A. Sudin, P. Yambun, H.S. Yong, J. Sukumaran, R.M. Brown. 2010. Phylogenetic relationships of Ansonia from Southeast Asia inferred from mitochondrial DNA sequences: systematic and biogeographic implications (Anura: Bufonidae). Mol. Phylogenet. Evol. 54. 561-570.

[5] Iskandar, D.T. 1998. The amphibians of Java and Bali. Research and Development Centre for Biology, Indonesian Institute of Science (LIPI), Bogor.

[6] Taylor, E.B., J.D. McPhail. 2000. Historical contigency and ecological determinism interact to rpime speciation in sticklebacks, Gasterterus. Proc. R. Soc. London Ser. B. 267. 2375-2384.

[7] taxo4254. Megophrys nasuta. Available at: https://taxo4254.wikispaces.com/Megophr ys+nasuta/megophrys nasuta.

[8] IUCN, 2015. Megophrys montana. Available at: http://www.iucnredlist.org/details/575 $81 / 0$.

[9] Swofford, D.L. 2002. PAUP*. Phylogenetic Analysis Using Parsimony (*and Other Methods), Version 4. Sinauer Associates, Sunderland, MA.

[10] Tanabe, A.S. 2007. Kakusan: a computer program to automate the selection of a nucleotide substitution model and the configuration of a mixed model on multilocus data. Mol. Ecol. Notes. 7. 962964.

[11] Huelsenbeck, J.P., F.R. Ronquist. 2001. MrBayes: Bayesian inference of phylogenetic trees. Bioinformatics. 17. 754-755.
[12] Felsensenstein, J. 1985. Confidence limits on phylogenies: an approach using the bootstrap. Evolution. 39. 783-791.

[13] Leaché, A.D., T.W. Reeder. 2002. Molecular systematics of the eastern fence lizard (Sceloporus undulatus): a comparison of parsimony, likelihood, and Bayesian approaches. Syst. Biol. 51. 44-68.

[14] Hall, R. 1998. The plate tectonics of Cenozoics SE Asia and the distribution of land and sea. In: Hall, R., J.D. Holloway (Eds). Biogeography and geological evolution of South East Asia. Backhuys Publishers, Leiden. 9-131.

[15] Mayr, E. 1963. Animal species and evolution. Cambridge, MA, Belknap.

[16] Utuyama, D.J., G.C. Mayer. 1980. Nonallopatric speciation in animals. Syst. Zool. 29. 254-271.

[17] Coyne, J.A., H.A. Orr. 2004. Speciation. Sunderland, MA, Sinauer.

[18] Stuessy, T.F., H. Weiss-Schneeweiss, D.J. Keil. 2004. Diploid and polyploid cytotype distribution in Melampodium cinereum and M. leucanthum (Asteraceare, Heliantheae). Am. J. Bot. 91. 889-898.

[19] Taylor, E.B., J.D. McPhail. 2000. Historical contingency and ecological determinism interact to prime speciation in sticklebacks, Gasterosteus. Proc. R. Soc. London Ser. B. 267. 2375-2384.

[20] Moritz, C., J.L. Patton, C.J. Schneider, T.B. Smith. 2000. Diversification of rainforest faunas: an integrated molecular approach. Annu. Rev. Ecol. Syst. 31. 533-563.

[21] Pyron, A.R., T.B. Frank. 2010. Hard and soft allopatry: physically and ecologically mediated modes of geographic speciation. J. Biogeogr. 37. 2005-2015.

[22] Kirkpatrick, M., N.H. Barton. 1997. Evolution of a species'range. T. Am. Nat. 150. 1-23.

[23] Costa, G.C., C.A. Wolfe, D.B. Shepard, J.P. Caldwell, L.J. Vitt. 2008. Detecting the influence of climatic variables on species' distributions: a tes using GIS niche-based models along a steep longitudinal environmental gradient. J. Biogeogr. 3. 637-646.

[24] McGuire, J.A., C.W. Linkem, M. Koo, D.W. Hutchison, A.K. Lappin, D.O. Orange, J. Lemos-Espinal, B.R. Riddle, J. Jaeger. 2007. Mitochondrial intogression and incomplete lineage sorting through space and time: phylogenetics of crotaphytid lizards. Evolution. 61. 2879-2897. 
[25] Hickerson, M.J., C.P. Meyer. 2008. Testing comparative phylogeographic models of marine vicariance and dispersal using a hierarchical Bayesian approach. BMC Evol. Biol. 8. 322.

[26] Burbrink, F.T., F.M. Fontanella, R.A. Pyron, T.J. Guiher, C. Jimenez. 2008. Phylogeography across a continent: the evolutionary and demographic history of the North American racer (Serpentes: Colubridae: Coluber constrictor). Mol. Phylogenet. Evol. 47. 274-288.

[27] McCaffrey, R. 2009. The tectonic framework of the Sumatran Subduction Zone. Annu. Rev. Earth Planet Sci. 2009. 37. 345-366.

[28] Ponto, C.V., C.EL. Wu, A. Pranoto, W. EL. Stinson. 1988. Improved interpretation of the Talang Akar depositional environment as an aid to hydrocarbon exploration in the ARII Offshore Northwest Java contract area. Proc. $17^{\text {th }}$ Annual Convention Indonesian Petroleum Association. 1. 397-422.

[29] Sudarmono, T. Suherman, B. Eza. 1997. Paleogene basin development in Sundaland and it's role to the petroleum systems in Western Indonesia. Proc. Indonesian Petroleum Association Petroleum Systems of SE Asia, May 1997. 545-560.

[30] Bishop, M.G. 2001. South Sumatra Basin Province Indonesia: The Lahat/Talang Akar Cenozoic Total Petroleum System. USGS Science for Changing World. 